\title{
UNIONS AND UNION MEMBERSHIP IN NEW ZEALAND: ANNUAL REVIEW FOR 2004
}

\author{
Leda Blackwood \\ Goldie Feinberg-Danieli \\ George Lafferty
}

\author{
Industrial Relations Centre \\ Victoria University of Wellington
}

\section{Introduction}

This paper reports the results of Victoria University's Industrial Relations Centre's annual survey of trade union membership in New Zealand for 2004. The survey has been conducted since 1991, when the Employment Contracts Act 1991 (ECA) ended the practice of union registration and the collection of official data. This year we report changes in union membership, composition, and density from December 2003 to December 2004, taking an historical perspective to compare the industrial relations periods framed by the ECA and the Employment Relations Act 2000 (ERA).

For the year to December 2004, union membership increased by 3.6 percent (a net increase of 12,427 members). This builds on five years of growth with an overall 17 percent increase since 1999 (Crawford, Harbridge, \& Walsh, 2000). Moreover, union density is 21.1 percent, slightly down from 2003 due to union recruitment not keeping pace with strong labour force growth $(4.8 \%$ for wage and salary earners) over the year (May, Walsh, \& Otto, 2004). Notwithstanding a recent decline in members in retail, wholesale, restaurants and hotels, the last eight years has shown consistent membership growth - this has outstripped growth in wage and salary earners (Crawford, Harbridge, \& Hince, 1997). Conversely, manufacturing - which is also a large employer - has seen a steady decline in union membership over the same period. This decline is from a relatively large membership base and more than onequarter of wage and salary earners in manufacturing remain members of their union.

\section{Methodology}

Our survey included only those unions registered as at 31 December, 2004, as per the Department of Labour website of registered unions (see www.ers.dol.govt.nz/ union/registration.html and DOL Annual Report 2004). In late January 2005, each of the registered unions was sent a survey requesting membership numbers as at 31 December 2004. One hundred and four unions responded. For those that did not, details were obtained either through telephone contact, or based on last year's figures verified by the Registrar of Unions (DOL, 2004, 2005). In the time between last year's survey and the return of this year's survey, 13 unions deregistered and two new unions registered, bringing the total number of unions to 170 (see Appendix for explanation of union registration under ERA).

\section{Trade union membership and density}

Table 1 shows trade union membership and density since 1991. Union density is defined as the proportion of potential union members who belong to a union.' One commonly used measure of union density is based on the total employed labour force. We present this figure here, but note that it includes people who are not usually potential union members (for example, employers, selfemployed and unpaid family members). A more accurate measure of union density is also presented - this figure is based on wage and salary earners only.

In 2004 , total union membership increased by 3.6 percent $(12,427$ members). This builds on the five years of growth since the introduction of the ERA, producing an overall 17 percent increase in union membership since the nadir of 302,405 in 1999 (Crawford, Harbridge, \& Walsh, 2000). For unions working to rebuild after the devastation of the ECA period, this is an encouraging sign.

Although union membership showed strong growth in 2004 , it did not keep pace with the even stronger growth in the labour force generally $(4.4 \%)$ and in the wage and salary earners component $(4.8 \%)$. As a consequence, there was a slight decrease in union density of 0.1 and 0.3 percent respectively. Union density has now been hovering between 21 and 22 percent since 1998 (Crawford, Harbridge, \& Hince, 1999), during a period of strong labour force growth coupled with high natural membership attrition (for example, through retirement and turnover). A slowing economy and slowing labour force growth - as widely predicted - coupled with the continuation of current trends in union membership growth, should see an increase in union density.

*Leda Blackwood, Goldie Feinberg-Danieli and George Lafferty are Senior Research Fellow; Project Coordinator; and Director respectively, at the Industrial Relations Centre, Victoria University of Wellington. This study is part of a larger project which receives funding from the Foundation for Research, Science and Technology (Contract no. Vic X0301). The authors are grateful to all the union officials who assisted with this research. 


\begin{tabular}{|c|c|c|c|c|c|c|}
\hline \multirow[b]{2}{*}{ Year } & \multirow[b]{2}{*}{$\begin{array}{l}\text { Union } \\
\text { member } \\
\text { ship } \\
\text { (1) }\end{array}$} & \multirow[b]{2}{*}{$\begin{array}{l}\text { Number of } \\
\text { unions } \\
\text { (2) }\end{array}$} & \multicolumn{2}{|c|}{$\begin{array}{c}\text { Potential union } \\
\text { membership }\end{array}$} & \multicolumn{2}{|c|}{ Union density } \\
\hline & & & $\begin{array}{c}\text { Total } \\
\text { employed } \\
\text { labour force } \\
\text { (3) }\end{array}$ & $\begin{array}{l}\text { Wage and } \\
\text { salary } \\
\text { earners } \\
\text { (4) }\end{array}$ & $\begin{array}{c}\text { (1) / (3) } \\
\% \\
(5)\end{array}$ & $\begin{array}{c}(1) /(4) \\
\% \\
\\
(6)\end{array}$ \\
\hline Dec 1991 & 514325 & 66 & 1518800 & 1196100 & 33.9 & 43.0 \\
\hline Dec 1992 & 428160 & 58 & 1539500 & 1203900 & 27.8 & 35.6 \\
\hline Dec 1993 & 409112 & 67 & 1586600 & 1241300 & 25.8 & 33.0 \\
\hline Dec 1994 & 375906 & 82 & 1664900 & 1314100 & 22.6 & 28.6 \\
\hline Dec 1995 & 362200 & 82 & 1730700 & 1357500 & 20.9 & 26.7 \\
\hline Dec 1996 & 338967 & 83 & 1768200 & 1409300 & 19.2 & 24.1 \\
\hline Dec 1997 & 327800 & 80 & 1773200 & 1424000 & 18.5 & 23.0 \\
\hline Dec 1998 & 306687 & 83 & 1760900 & 1399100 & 17.4 & 21.9 \\
\hline Dec 1999 & 302405 & 82 & 1810300 & 1435900 & 16.7 & 21.1 \\
\hline Dec 2000 & 318519 & 134 & 1848100 & 1477300 & 17.2 & 21.6 \\
\hline Dec 2001 & 329919 & 165 & 1891900 & 1524900 & 17.4 & 21.6 \\
\hline Dec 2002 & 334783 & 174 & 1935600 & 1566400 & 17.3 & 21.4 \\
\hline Dec 2003 & 341631 & 181 & 1986100 & 1598700 & 17.2 & 21.4 \\
\hline Dec 2004 & 354058 & 170 & 2073800 & 1676200 & 17.1 & 21.1 \\
\hline
\end{tabular}

Source: Household Labour Force Survey, Table 3. Table 4.3 (unpublished), HL.FQ.SAA3AZ, Industrial Relations Centre Survey

Note: Figures in columns 3,4,5\& 6 are different to those reported in previous years due to a population rebase by Statistics NZ in June 2004, see HLFS population rebase: June 2004 quarter, July 2004)

Figure 1: Distribution of wage and salary earners across industry sectors

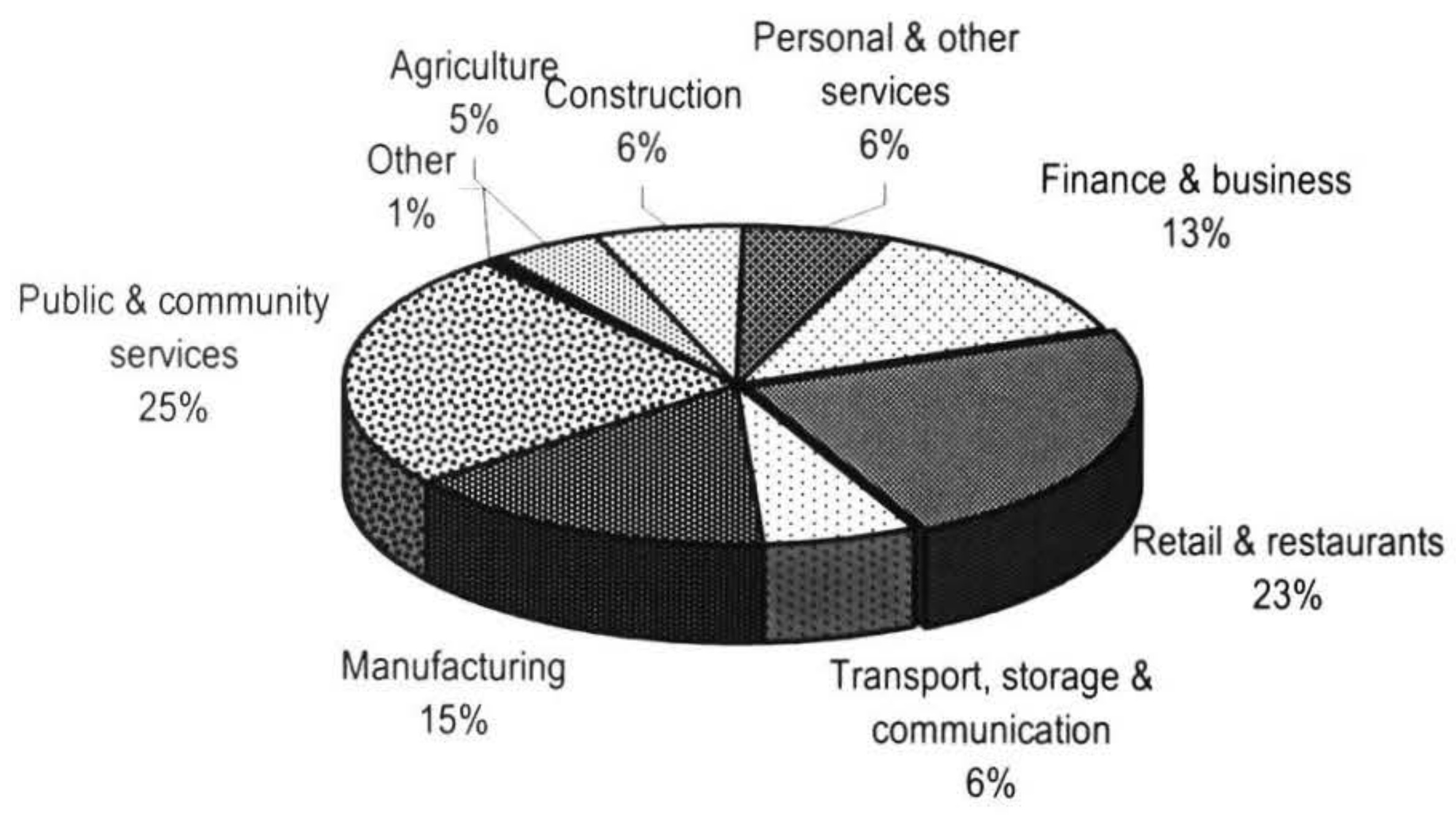


Figure 2: Distribution of union members across industry sectors

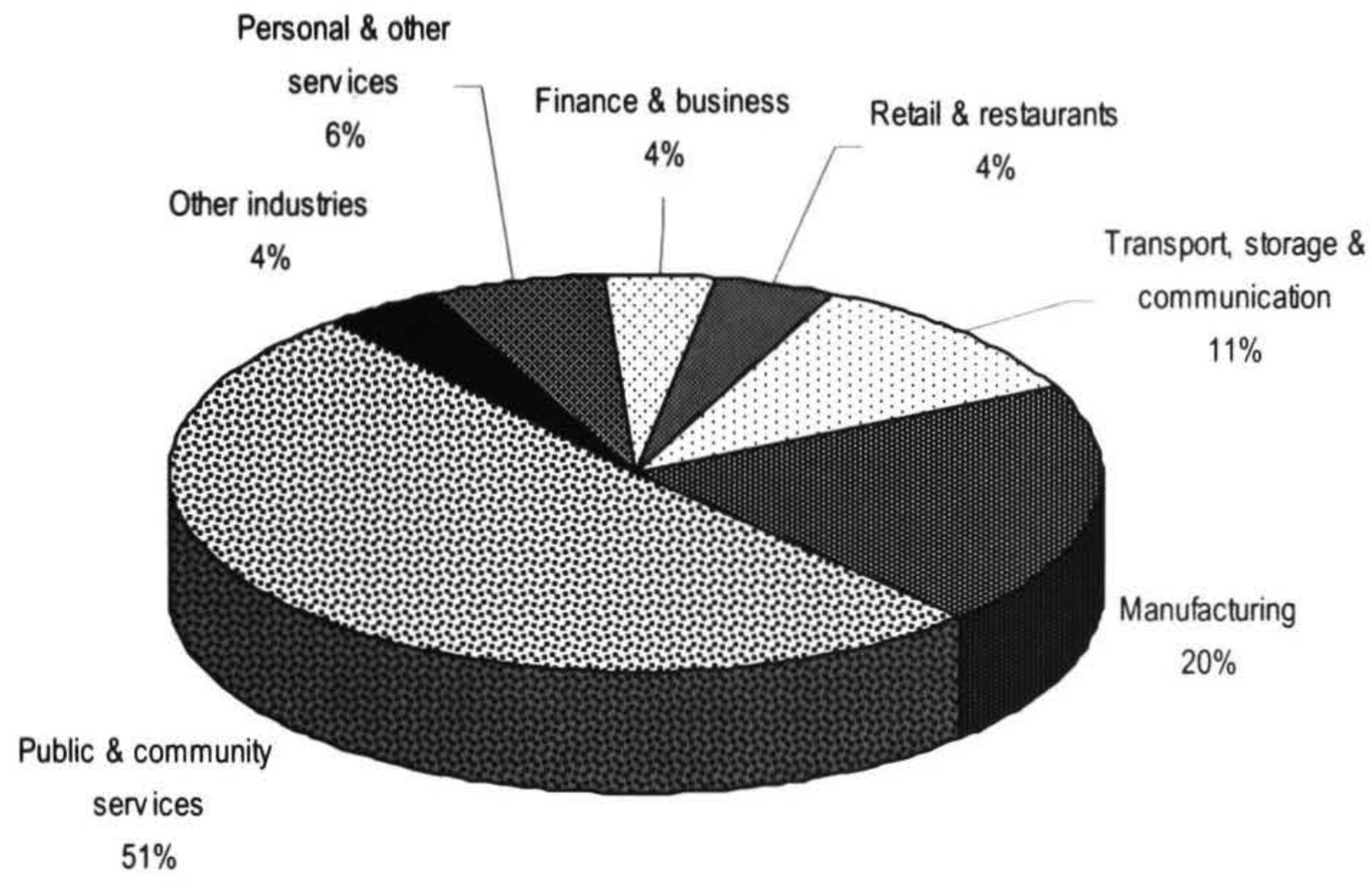

\section{Union membership and employment by industry}

In this section we look at the distribution of wage and salary earners (see Figure 1) and of union members (see Figure 2), across industry sectors (classified according to the Australia New Zealand Standard Industry Classification). This provides a more nuanced picture of patterns of union representation in the New Zealand context.

In December 2004, the largest concentrations of New Zealand wage and salary earners were in public and community services $(25 \%)$; retail, wholesale, restaurants, and hotels (23\%); manufacturing (15\%); and finance, insurance and business services sectors (13\%: see Figure 1). Union membership was overwhelming concentrated in public and community services $(51 \%)$, followed by manufacturing $(20 \%)$ and transport, storage and communication sectors $(11 \%$ : see Figure 2). These sectors are not major growth areas of the labour force (Statistics New Zealand, unpublished tables). In contrast, the large retail, wholesale, restaurants, and hotels sector which employs 23 percent of all wage and salary earners and is a growth area had only four percent of total union membership.

\section{Change in union membership and employment by industry}

Table 2 examines gains and losses in membership by industry and Table 3 compares these with changes in wage and salary earner employment.

When we examined changes in union membership from the previous year, the largest gains were in public and community services (particularly health); transport, storage and communications; and personal and other services. These three sectors accounted for 43 percent, 29 percent, and 16 percent, respectively, of the increase in union members. Coming off a small membership base, mining experienced very strong membership growth of 62 percent.

Conversely, in the large retail, wholesale, restaurants, hotels and manufacturing sectors, considerable losses in membership were reported. This is an important, yet difficult industry sector in which to recruit (and retain) members due to high levels of part-time and casual work, and high turnover - particularly in times of strong economic growth. Reflecting the volatility in this sector, the 11 percent loss of members in retail, wholesale, restaurants, and hotels followed a ten percent increase in the previous year. 


\begin{tabular}{|c|c|c|c|c|c|}
\hline \multirow[t]{2}{*}{ Industry group } & \multirow{2}{*}{ Dec 2003} & \multirow{2}{*}{ Dec 2004} & \multicolumn{2}{|c|}{ Change 2003-2004 } & \multirow{2}{*}{$\begin{array}{c}\text { New } \\
\text { members } \\
\text { breakdown } \\
\% \\
\end{array}$} \\
\hline & & & Num & $(\%)$ & \\
\hline Agriculture, fishing, forestry etc & 3656 & 3417 & -239 & -7 & -2 \\
\hline Mining and related services & 1029 & 1668 & 639 & 62 & 5 \\
\hline Manufacturing & 71936 & 71504 & -432 & -1 & -3 \\
\hline Energy and utility services & 3763 & 4628 & 865 & 23 & 7 \\
\hline Construction \& building services & 6201 & 5729 & -472 & -8 & -4 \\
\hline Retail, wholesale, restaurants, hotels & 17849 & 15861 & -1988 & -11 & -16 \\
\hline Transport, storage and communication & 34153 & 38692 & 4539 & 13 & 37 \\
\hline Finance, Insurance and business services & 13148 & 13402 & 254 & 2 & 2 \\
\hline Personal and other services & 17427 & 19974 & 2547 & 15 & 20 \\
\hline Public and community services & 172469 & 179183 & 6714 & 4 & 54 \\
\hline Govt admin and defence & 33735 & 35048 & 1313 & 4 & 11 \\
\hline Education & 75164 & 76909 & 1745 & 2 & 14 \\
\hline Health & 63570 & 67225 & 3655 & 5 & 29 \\
\hline TOTAL & 341631 & 354058 & 12427 & 3.6 & $\begin{array}{r}100 \\
(12427)\end{array}$ \\
\hline Membership private sector & 160208 & 163927 & 3719 & 2.3 & 30 \\
\hline Membership public sector & 181423 & 190131 & 8708 & 4.8 & 70 \\
\hline
\end{tabular}

Source: Industrial Relations Centre Survey, 2004

Table 3: Union membership change and labour force change 2003 - 2004

\begin{tabular}{|c|c|c|c|c|}
\hline Industry group & $\begin{array}{c}\text { Union } \\
\text { membership } \\
\text { Dec } 2004\end{array}$ & $\begin{array}{c}\text { Change in } \\
\text { membership } \\
2003-2004 \\
\%\end{array}$ & $\begin{array}{c}\text { Labour force } \\
\text { Dec } 2004 \\
(000)\end{array}$ & $\begin{array}{c}\text { Change in } \\
\text { labour force } \\
2003-2004 \\
\% \\
\end{array}$ \\
\hline Agriculture, fishing, forestry etc & 3417 & -7 & 75.6 & 0 \\
\hline Mining and related services & 1668 & 62 & 6 & 54 \\
\hline Manufacturing & 71504 & -1 & 259 & 4 \\
\hline Energy and utility services & 4628 & 23 & 8.9 & -6 \\
\hline Construction \& building services & 5729 & -8 & 99.2 & 9 \\
\hline Retail, wholesale, restaurants, hotels & 15861 & -11 & 392.6 & 2 \\
\hline Transport, storage and communication & 38692 & 13 & 105.5 & 5 \\
\hline Finance, Insurance and business services & 13402 & 2 & 211.1 & 10 \\
\hline Personal and other services & 19974 & 15 & 105.3 & -3 \\
\hline Public and community services & 179183 & 4 & 411 & 8 \\
\hline - Govt admin and defence & 35048 & 4 & 78.0 & 5 \\
\hline - Education & 76909 & 2 & 158.6 & 8 \\
\hline - Health and community & 67225 & 5 & 174.4 & 9 \\
\hline TOTAL & 354058 & 3.6 & 1676.2 & 4.8 \\
\hline
\end{tabular}

Source: Industrial Relations Centre Survey, 2004 
Table 4: Union Density - public and private sectors in selected countries (2005)

\begin{tabular}{lccc|}
\hline Country & Union density & Public sector & Private sector \\
\hline New Zealand & 21 & 66 & 12 \\
Australia & 23 & 46 & 17 \\
Canada & 30 & 70 & 18 \\
UK & 26 & 60 & 17 \\
USA & 13 & 36 & 8 \\
\hline
\end{tabular}

Source: Statistics New Zealand, QES March 2005; Australian Bureau of Statistics 2005; Human Resources and Skills Development Canada 2005; UK

Dept of Trade and Industry 2005; US Dept of Labor 2005; Industrial Relations Survey, 2004

Changes in union density

Table 5: Density by industry 2003, 2004

\begin{tabular}{lcc}
\hline & Approx. density & Approx. density \\
Industry group & $2003(\%)$ & $2004(\%)$ \\
\hline Agriculture, fishing, forestry etc & 4.8 & 4.5 \\
Mining and related services & 26.4 & 27.8 \\
Manufacturing & 29.0 & 27.6 \\
Energy and utility services & 39.6 & 52.0 \\
Construction \& building services & 6.8 & 5.8 \\
Retail, wholesale, restaurants, hotels & 5.1 & 4.0 \\
Transport, storage communication & 34.1 & 36.7 \\
Finance, insurance \& business services & 6.8 & 6.3 \\
Personal and other services & 16.0 & 19.0 \\
Public and community services & 45.1 & 43.6 \\
- Govt administration \& defence & 48.3 & 44.9 \\
- Education & 51.0 & 48.5 \\
Health \& community services & 39.5 & 38.5 \\
\hline
\end{tabular}

Source: Household Labour Force Survey - wage and salary earners component, unpublished, Statistics New Zealand, 2004. Industrial Relations Centre Survey

Table 6: Changes in wage \& salary earners and union membership, $1996-2003$

\begin{tabular}{l|r|r|r|r}
\hline Industry group & $\begin{array}{c}\text { Labour force } \\
\text { Dec 1996 } \\
(000)\end{array}$ & $\begin{array}{c}\text { Labour force } \\
\text { Dec 2004 } \\
(000)\end{array}$ & $\begin{array}{c}\text { Labour force } \\
\text { change } \\
1996-2004 \\
(\%)\end{array}$ & $\begin{array}{c}\text { Union } \\
\text { membership } \\
1996-2004 \\
(\%)\end{array}$ \\
\hline Agriculture, fishing, forestry etc & 67.8 & 75.6 & 11.5 & 218.5 \\
Mining and related services & 2.7 & 6.0 & 122.2 & 45.8 \\
Manufacturing & 248.1 & 259.0 & 4.4 & -9.2 \\
Energy and utility services & 12.5 & 8.9 & -28.8 & -23.9 \\
Construction \& building services & 72.3 & 99.2 & 37.2 & -12.9 \\
Retail, wholesale, restaurants, hotels & 321.0 & 392.6 & 22.3 & 49.0 \\
Transport, storage and communication & 87.7 & 105.5 & 20.3 & -10.2 \\
Finance, Insurance and business services & 175.5 & 211.1 & 20.3 & -47.5 \\
*Public, community \& personal services & 417.9 & 518.4 & 24.0 & 19.9 \\
(includes some private sector employment) & & & & $\mathbf{4 . 5}$ \\
\hline TOTAL & $\mathbf{1 4 0 8 . 3}$ & $\mathbf{1 5 9 8 . 7}$ & $\mathbf{1 3 . 5}$ & \\
\hline
\end{tabular}

Source: Household Labour Force Survey, wage and salary earners component, 1996\& 2004, unpublished, Statistics New Zealand

- Note: Public and community services and personal and other services are combined for the purpose of comparison with 1996 figures. 
Of concern for unions will be the ongoing decline in manufacturing, which accounts for the largest proportion of union members in the private sector. The one percent drop in union membership in manufacturing in 2004 is on the back of a three percent decline in 2003 and a one percent decline in 2002 (May, Walsh, \& Otto, 2004; May, Walsh, Thickett, \& Harbridge, 2003). This decline is largely attributed to the loss of unionised jobs overseas, and high attrition through retirement for this aging sector of the workforce.

\section{Public / private divide}

In addition to industry breakdown, our survey asks unions to estimate how many of their members work in the private sector and the public sector. With the substantial membership gains in public, community and other services, most union membership growth was from the public sector $(70 \%)$. Moreover, 53.7 percent of all union members are employed in the public sector - up from 53.1 percent in 2003 (May, Walsh, \& Otto, 2004).

The preponderance of union membership in the public sector, which accounts for only one-quarter of all wage and salary earners in New Zealand, is reflected in a public/private divide in union density figures. We have used the Quarterly Employment Survey (QES) to estimate total employment by public and private sector. Table 4 shows that the public/private divide in New Zealand is somewhat greater than in our main international comparators (Blackwood, Feinberg-Danieli \& Lafferty, 2005)

\section{Changes in union density}

Table 5 shows the density figures by industry for 2003 and 2004. Density has been calculated by using the wage and salary earners only component of the Household Labour Force survey, thus eliminating the self-employed and employers from the calculations. Government administration and defence, education, and health and community services continue to be strongly unionised. So too do energy and utility services, transport, storage and communications, mining, and manufacturing - although there has been some slippage in the latter. Unions, however, are struggling to maintain a presence in the remaining industries which are predominantly private sector.

\section{Changes in union membership and density 1996 and 2004}

Table 6 shows that the number of wage and salary earners in New Zealand grew by 13.5 percent in the eight years between December 1996 and December 2004, while union membership grew by only 4.5 percent. Disguised within these figures, however, is an 11 percent drop in union membership between 1996 and 1999, followed by a 17 percent increase between 1999 and 2004 (Crawford, Harbridge, \& Hince, 1997; Crawford, Harbridge, \& Walsh, 2000).

Union membership growth has outstripped employment growth in retail, wholesale, restaurants, and hotels - large employers of wage and salary earners, experiencing sustained growth. Sectors where strong employment growth has outstripped membership growth, producing a decline in density, include mining and related services, construction and related services, and transport, storage and communication. These are relatively small industry sectors, however, so the failure of union membership to keep up with employment growth has not had too great an impact on overall density figures. Of more concern is the decline in membership in manufacturing - a large, though not rapidly growing, area of employment - and in finance and business services.

\section{Gender and ethnicity}

Women comprise only 46 percent of the New Zealand labour force (Household Labour Force Survey, Dec 2004 Table 3, Statistics New Zealand 2004), yet constitute 52 percent of union membership. This strong participation rate reflects women's high representation in public and community services and has been evident for the last decade with around 48-50 percent of union membership being female. This year only 27 unions advised that they collected statistics on ethnicity. These unions covered 133,969 employees or 38 percent of total union members. Table 7 shows a higher representation of Maori and Pacific Islander peoples than their representation in the labour force would lead us to expect. Interpretation of these figures needs to be tentative as inspection of survey returns suggests that some unions may be placing employees for whom they do not have ethnicity information in the 'Other' category.

\section{Trade union numbers, distribution of membership by size, and affiliation}

Table 8 shows the number of identifiable trade unions, categorised by size, at the commencement and conclusion of the ECA period (1991 and 1999 respectively: Crawford, Harbridge \& Walsh, 2000; Harbridge \& Hince, 1993), and four years into the ERA period (2004). Refer to Table 1 for the number of trade unions for all years from 1991 onwards. 
Table 7: Ethnicity by sample and labour force 2004 - where details are provided

\begin{tabular}{l|c|c}
\hline Ethnic group & Survey sample & $\begin{array}{c}\text { Total labour force* } \\
\text { (\%) }\end{array}$ \\
\hline NZ European: & $\mathbf{( \% )}$ & 77.7 \\
Maori: & 50.4 & 9.6 \\
Pacific Peoples: & 11.5 & 4.5 \\
Asian: & 10.1 & N/a \\
Other: & 1.5 & 8.2 \\
Total & 26.4 & $\mathbf{1 0 0}$ \\
\hline
\end{tabular}

- Statistics New Zealand, Household Labour Force Survey, December Quarter 2004, table 5. No breakdown given for Asian working population

Table 8: Membership by union size 1991 - 2004, selected years

\begin{tabular}{l|r|r|r|r|r|r|r|r|r}
\hline $\begin{array}{l}\text { M'ship } \\
\text { range }\end{array}$ & \multicolumn{3}{|c|}{ May 1991 } & \multicolumn{3}{c|}{ Dec 1999 } & \multicolumn{3}{c}{ Dec 2004 } \\
\hline Under 1000 & 4 & 2954 & 1 & 48 & 12703 & 4 & 133 & 19561 & 6 \\
$1000-4999$ & 48 & 99096 & 16 & 22 & 43709 & 14 & 24 & 51689 & 15 \\
$5000-9999$ & 8 & 64268 & 11 & 3 & 19669 & 7 & 5 & 36147 & 10 \\
$10000+$ & 20 & 436800 & 72 & 9 & 226324 & 75 & 8 & 246661 & 70 \\
\hline Totals & $\mathbf{8 0}$ & $\mathbf{6 0 3 1 1 8}$ & $\mathbf{1 0 0}$ & $\mathbf{8 2}$ & $\mathbf{3 0 2 4 0 5}$ & $\mathbf{1 0 0}$ & $\mathbf{1 7 0}$ & $\mathbf{3 5 4 0 5 8}$ & $\mathbf{1 0 0}$ \\
Av. Size & & $\mathbf{7 5 3 9}$ & & & $\mathbf{3 6 8 8}$ & & & $\mathbf{2 0 8 3}$ & \\
\hline
\end{tabular}

Source: Industrial Relations Centre Survey

Table 9: NZCTU affiliation 1991 - 2004

\begin{tabular}{cc|c|c}
\hline Year & NZCTU Affiliate unions & Members & $\begin{array}{c}\text { Percentage of total m'ship } \\
\text { in CTU affiliates }\end{array}$ \\
\hline $\mathbf{1 9 9 1}$ & 43 & 445116 & 86.5 \\
$\mathbf{1 9 9 2}$ & 33 & 339261 & 79.2 \\
$\mathbf{1 9 9 3}$ & 33 & 321119 & 78.5 \\
$\mathbf{1 9 9 4}$ & 27 & 296959 & 78.9 \\
$\mathbf{1 9 9 5}$ & 25 & 284383 & 78.5 \\
$\mathbf{1 9 9 6}$ & 22 & 278463 & 82.2 \\
$\mathbf{1 9 9 7}$ & 20 & 253578 & 77.4 \\
$\mathbf{1 9 9 8}$ & 19 & 238262 & 77.7 \\
$\mathbf{1 9 9 9}$ & 19 & 235744 & 78.0 \\
$\mathbf{2 0 0 0}$ & 26 & 273570 & 85.9 \\
$\mathbf{2 0 0 1}$ & 32 & 289732 & 87.8 \\
$\mathbf{2 0 0 2}$ & 34 & 293466 & 87.7 \\
$\mathbf{2 0 0 3}$ & 36 & 297440 & 87.1 \\
$\mathbf{2 0 0 4}$ & 38 & 310451 & 87.7 \\
\hline
\end{tabular}

Source: Industrial Relations Centre surveys 
The only clear effects of regulatory regimes on the industrial relations landscape in New Zealand are in relation to the number of trade unions. The requirement in the Labour Relations Act 1987, that unions have a minimum membership of 1000 , set in motion union amalgamations and mergers leading to a dramatic drop in trade union numbers from 259 in 1985 to 104 in 1990. The ECA (1991) abolished registration provisions making identification of unions difficult. Estimates suggest, however, that there was a further drop in numbers during this period, varying between 58 in 1992 and 83 in 1996. Reversing this decline, the ERA's requirement that only registered unions could participate in collective bargaining, and its setting of a low membership threshold for registration at 15 members, saw the number of registered unions more than double to a high of 181 in 2003 (see Table 1 and May, Walsh \& Otto, 2004).

Although the ERA has seen a growth in the number of unions, most new unions are small, enterprise or workplace based, and do not see themselves as unions in the traditional sense. Many exist solely for the purposes of negotiating a collective agreement and they tend to have extremely limited resources. Moreover, their entry has done little to change the distribution of union membership. Small unions (those with fewer than 1000 members) still only account for 6 percent of overall membership, and large unions (those with more than 10,000 members) account for 70 percent of all membership. It is these large, well established, and better resourced unions that account for most of the membership growth (May, Walsh \& Otto, 2004).

\section{Peak bodv affiliations}

Only 38 of the 170 registered unions are CTU affiliates (see Table 9). However, with 310,451 members, CTU affiliates have 88 percent of total union membership and represent 17 of the 20 largest unions in New Zealand. This proportion has been consistent throughout the period of the ERA. Moreover, in the year to December 2004, CTU affiliated unions increased their membership by 13.011. In contrast, 584 members were lost from nonaffiliated unions

\section{Discussion}

The union movement has been successful during recent years in arresting the precipitous 1990s decline in both membership and density. The number of union members has increased consistently over the past five years, while density has remained at a stable, albeit historically low, level. While membership growth has been slightly outstripped by overall labour market growth within an expanding economy, the widely-predicted economic slowdown could well see an increase in union density, as labour turnover declines and fewer new casual or shortterm jobs are created in such lowly-unionised areas as retail, wholesale, restaurants and hospitality Where people have fewer alternative labour market opportunities, they are more inclined to remain in their current positions - a situation that should be more conducive to union membership. Unions might also seek to address the problem of retention directly, through making it easier for individual employees to retain their union membership, while moving between jobs.

The legislative environment established by the Employment Relations Act 2000, and its subsequent amendments, has no doubt contributed to this relative success for the union movement - a situation that is likely to remain reasonably favourable for unions in the foreseeable future. At the time of writing, it has been confirmed that Helen Clark will continue to be Prime Minister in a Labour-led government. In such a context, a dramatic shift from the ERA's moderate support for collective bargaining, union membership and good faith in the employment relationship should continue.

Major challenges remain, however. Unions continue to be handicapped by the persistence of free-riding: despite legislative encouragement for collective bargaining, many non-union members continue to benefit from the flow-on of pay and conditions previously negotiated by unions. The amendments to the ERA in December 2004 may prove at most a minor impediment to the continuation of this practice. The low incidence of both union membership and collective bargaining in the private sector also stands out as an important issue: the public sector has increasingly emerged as the contemporary union heartland, while some traditional private sector areas of union strength (most notably, manufacturing) have exhibited a decline. There are signs, though, that successful campaigns in 2005, such as the EPMU's 'five in $05^{\circ}$, have attracted considerable momentum and generated greater support for unionism in the private sector. In short, therefore, the overall trend is reasonably encouraging for unions and the labour movement, but still the great majority of New Zealand's employees remain non-unionised. The reinvigoration of the union movement has gained some strength, though, with the NZCTU and several key unions playing significant roles.

\section{References:}

Australian Bureau of Statistics (2005), catalogue 6310.0 Employee Earnings, Benefits and Trade Union Membership. Canberra: ABS.

Blackwood, L., Feinberg-Danieli, G., and Lafferty, G. (2005), Employment Agreements: Bargaining Trends and Employment Law Update 2004/2005, IRC, Victoria University of Wellington.

Crawford, A., Harbridge, R., \& Hince, K. (1997), Unions and Union Membership in New Zealand: Annual Review for 1996. New Zealand Journal of Industrial Relations, 22(2): 209-216.

Crawford, A., Harbridge, R., \& Hince, K. (1999), Unions and Union Membership in New Zealand: Annual Review for 1998. New Zealand Journal of Industrial Relations, 24(3).

Crawford, A., Harbridge, R., \& Walsh, P. (2000), Unions and Union Membership in New Zealand: 
Annual Review for 1999, Working Paper 11/00, IRC, Victoria University of Wellington.

Department of Labor (2005), Union Members Survey, Department of Labor: Washington D.C: Dept of Labor.

Department of Trade and Industry (2005), Trade Union Membership 2004, London: DTI.

Department of Labour (2004), ERA Info, Volume 16, July 2004 , DOL.

Department of Labour (2005), Unpublished data, DOL. ERS Website

www.ers.dol.govt.nz/union/registration.html

Harbridge, R., \& Hince, K. (1993), Unions and Union Membership in New Zealand 1985 - 1992. New Zealand Journal of Industrial Relations, 18(3): 352-361.

Human Resources and Skills Development Canada (2005), Union Membership in Canada - 2004, Ottawa: HRSDC.

May, R., Walsh, P., Thickett, G., \& Harbridge, G. (2003), 'Unions and Union Membership in New Zealand: Annual Review for 2002', New Zealand Journal of Industrial Relations, 28 (3): 314-325.

May, R., Walsh, P., \& Otto, C. (2004), 'Unions and Union Membership in New Zealand: Annual Review for 2003', New Zealand Journal of Employment Relations, 29 (3): 83-96.

Statistics New Zealand (2002, 2003, 2004), Household Labour Force Survey, unpublished reports.

Statistics New Zealand (2005), Quarterly Employment Survey, March 2005.

\section{Appendix}

\section{The Employment Relations Act and Trade Union Registration}

The objects of the Act with respect to the recognition and operation of unions are:

- To recognise the role of unions in promoting their members' collective interests

- To provide for the registration of unions that are accountable to their members

- To confer on registered unions the right to represent their members in collective bargaining

- To provide representatives of registered unions with reasonable access to workplaces for purposes related to employment and union business.

In pursuit of these objectives, the ERA establishes a union registration system, and grants registered unions bargaining rights together with rights of access to workplaces (specified in sections 19-25). To gain registration, a union must have more than 15 members, and provide a statutory declaration that it complies with the requirements of $\mathrm{s} 14$ of the Act regarding rules, incorporation and independence from employers. The Act requires the statutory declaration to stipulate that the union is 'independent of, and is constituted and operates at arm's length from any employer' (s/4(1)d). The Registrar of Unions may rely on the statutory declaration to establish entitlement to registration. Only registered unions may negotiate collective agreements, and collective agreements apply only to union members whose work falls within the agreement's coverage clause, and to new workers whose work falls within the agreement's coverage clause for the first 30 days of their employment.

' The measure of potential union members used to calculate union density varies from country to country and there is no agreed 'correct' method. Consistency in reporting so that results can be compared year on year is, though, a priority. 